\title{
Article \\ Old Question Revisited: Are High-Protein Diets Safe in Pregnancy?
}

\author{
Thorhallur I. Halldorsson 1,2,*, Bryndis E. Birgisdottir ${ }^{1}\left(\right.$, Anne L. Brantsæter ${ }^{3}{ }^{(}$, Helle Margrete Meltzer ${ }^{3}{ }^{(0)}$, \\ Margaretha Haugen ${ }^{3}$, Inga Thorsdottir ${ }^{1}$, Anna S. Olafsdottir ${ }^{4}$ and Sjurdur F. Olsen ${ }^{2,5}$ \\ 1 Faculty of Food Science and Nutrition, School of Health Sciences, University of Iceland, \\ 101 Reykjavik, Iceland; beb@hi.is (B.E.B.); ingathor@hi.is (I.T.) \\ 2 Centre for Foetal Programming, Department of Epidemiology Research, Statens Serum Institut, \\ 2300 Copenhagen, Denmark; SFO@ssi.dk \\ 3 Division of Infection Control and Environmental Health, Norwegian Institute of Public Health, \\ 0213 Oslo, Norway; annelise.brantsaeter@fhi.no (A.L.B.); hellemargrete.meltzer@fhi.no (H.M.M.); \\ almargar@online.no (M.H.) \\ 4 Faculty of Health Promotion, Sport and Leisure Studies, School of Education, University of Iceland, \\ 105 Reykjavik, Iceland; annaso@hi.is \\ 5 Department of Nutrition, Harvard TH Chan School of Public Health, Boston, MA 02115, USA \\ * Correspondence: tih@hi.is; Tel.: +354-525-4000
}

Citation: Halldorsson, T.I.;

Birgisdottir, B.E.; Brantsæter, A.L.; Meltzer, H.M.; Haugen, M.;

Thorsdottir, I.; Olafsdottir, A.S.; Olsen,

S.F. Old Question Revisited: Are

High-Protein Diets Safe in

Pregnancy? Nutrients 2021, 13, 440.

https://doi.org/10.3390/nu13020440

Received: 29 November 2020

Accepted: 24 January 2021

Published: 29 January 2021

Publisher's Note: MDPI stays neutral with regard to jurisdictional claims in published maps and institutional affiliations.

Copyright: (c) 2021 by the authors. Licensee MDPI, Basel, Switzerland. This article is an open access article distributed under the terms and conditions of the Creative Commons Attribution (CC BY) license (https:// creativecommons.org/licenses/by/ $4.0 /)$.

\begin{abstract}
Background: A previous randomized dietary intervention in pregnant women from the 1970s, the Harlem Trial, reported retarded fetal growth and excesses of very early preterm births and neonatal deaths among those receiving high-protein supplementation. Due to ethical challenges, these findings have not been addressed in intervention settings. Exploring these findings in an observational setting requires large statistical power due to the low prevalence of these outcomes. The aim of this study was to investigate if the findings on high protein intake could be replicated in an observational setting by combining data from two large birth cohorts. Methods: Individual participant data on singleton pregnancies from the Danish National Birth Cohort (DNBC) $(n=60,141)$ and the Norwegian Mother, Father and Child Cohort Study (MoBa) $(n=66,302)$ were merged after a thorough harmonization process. Diet was recorded in mid-pregnancy and information on birth outcomes was extracted from national birth registries. Results: The prevalence of preterm delivery, low birth weight and fetal and neonatal deaths was $4.77 \%, 2.93 \%, 0.28 \%$ and $0.17 \%$, respectively. Mean protein intake (standard deviation) was $89 \mathrm{~g} /$ day (23). Overall high protein intake (>100 g/day) was neither associated with low birth weight nor fetal or neonatal death. Mean birth weight was essentially unchanged at high protein intakes. A modest increased risk of preterm delivery [odds ratio (OR): 1.10 (95\% confidence interval (CI): 1.01, 1.19)] was observed for high (>100 g/day) compared to moderate protein intake (80-90 g/day). This estimate was driven by late preterm deliveries (weeks 34 to $<37$ ) and greater risk was not observed at more extreme intakes. Very low ( $<60 \mathrm{~g} /$ day) compared to moderate protein intake was associated with higher risk of having low-birth weight infants [OR: 1.59 (95\%CI: 1.25, 2.03)]. Conclusions: High protein intake was weakly associated with preterm delivery. Contrary to the results from the Harlem Trial, no indications of deleterious effects on fetal growth or perinatal mortality were observed.
\end{abstract}

Keywords: DNBC; MoBa; diet; protein; pregnancy; complications; preterm birth; fetal growth; perinatal mortality

\section{Introduction}

Forty years ago, a trial with high-protein supplementation in pregnancy, often referred to as the Harlem Trial, was undertaken in New York City [1]. Women were recruited from a poor urban African American population who had one or more risk factors for having a low-birth weight infant. The supplementation consisted of $40 \mathrm{~g}$ casein in liquid 
form corresponding to a daily intake of $\sim 100 \mathrm{~g}$ protein (or $\sim 20 \%$ of energy intake). The stated objectives of the trial were to "accelerate fetal growth and raise birth weight, and to influence later development". However, as described in the initial report [1], no beneficial effects were detected. Instead, the mean birth weight of infants born prior to 37th week of gestation was significantly reduced [1] and the risk of small-for-gestational age (SGA) was increased [2]. Increased risks of delivery prior to 30 weeks and neonatal deaths were also reported, although only on the verge of statistical significance [1]. The investigators concluded that "Review of all available published and unpublished data makes it clear that high density protein supplementation during pregnancy consistently retards fetal growth" [1]. Their recommendation was also clear: "high protein supplementation in pregnancy must surely be avoided, at least until better information becomes available" [1].

Ever since their initial publication, the findings from the Harlem Trial have had considerable influence on public health recommendations. As an example, the current WHO recommendations for antenatal care do not recommend high-protein supplementation in undernourished populations [3]. The results from this trial have also weighted heavily in dietary recommendations for well-nourished populations [4] and in conclusions of systematic reviews [2,5-7]. In contrast, observational studies in well-nourished populations [8-10] only reported a modest reduction in fetal growth at high maternal protein intakes. Those studies did not, however, address adverse outcomes such as fetal growth retardation and mortality. The recent wave of low-carbohydrate, high-protein ketogenic diets for weight loss [11,12] makes the case for reassessing the findings of the Harlem Trial of public health relevance. Observational studies sufficiently powered for such analyses are, however, rare.

Using prospective data on 126,443 singleton pregnancies from two large Nordic cohorts, we were able to identify more than 17,000 women who reported a protein intake in mid-pregnancy of at least $100 \mathrm{~g} / \mathrm{d}$. Our aim was to see if the associations with adverse pregnancy outcomes observed in the Harlem Trial could be replicated in this setting.

\section{Materials and Methods}

\subsection{Population and Study Design}

The Danish National Birth Cohort (DNBC: recruitment all over Denmark in 1996-2002, conducted at the Statens Serum Institut, Denmark) and the Norwegian Mother, Father and Child Cohort Study (MoBa: recruitment all over Norway in 1999-2008, conducted by the Norwegian Institute of Public Health) are prospective population-based pregnancy cohorts $[13,14]$. During the recruitment period, around 101,042 pregnancies or $35 \%$ of all pregnant women in Denmark were recruited into the DNBC. In MoBa, around $40.6 \%$ of all pregnant women were recruited and in total, the cohort includes 95,200 mothers, 75,200 fathers and their 114,500 children.

In the DNBC, women were recruited during their first antenatal visit to the general practitioner (gestational week $\sim 6$ ), whilst in $\mathrm{MoBa}$, pregnant women were invited to participate by mail prior to the first ultrasound examination in gestational week $\sim 18$. In both cohorts, a comparison between participants and non-participants from the general pregnant population has been performed, finding no indication of selection bias for selected birth outcomes, including preterm delivery and low birth weight $[15,16]$.

The MoBa dataset used for this study is based on version four of the quality-assured datafiles made available in 2008. Quality assurance here means that the electronically scanned version of the file was checked to reflect the exact answers given by respondents, including improbable answers, leaving it to the researchers to decide which answers to exclude. The MoBa data contained information on singleton pregnancies among participants answering a questionnaire on lifestyle and health in gestation week 15 (Q1) and a food frequency questionnaire (FFQ) in week 22 (Q2), in use from 2002 throughout the recruitment period. The DNBC data were from a quality-assured datafile containing information on women who answered an FFQ in mid-pregnancy and participated in two telephone interviews on lifestyle and health in gestational weeks 12 and 30. 
Written informed consent was obtained from all participants in both cohorts. The establishment and data collection in MoBa were previously based on a license from the Norwegian Data Protection Agency and approval from The Regional Committee for Medical Research Ethics (S-95113/S-97045). They are now based on regulations related to the Norwegian Health Registry Act. The regional scientific ethics committee for the municipalities of Copenhagen and Frederiksberg approved all DNBC study protocols (27 August 2013: H-2-2013-108). All procedures were in accordance with the Declaration of Helsinki.

\subsection{Inclusion Criteria}

In the DNBC, dietary information was available for a total of 70,183 pregnancies. Of those, 1078 and 1590 pregnancies were excluded due to unrealistically low ( $\leq 4.5 \mathrm{MJ})$ or high (>20.0 MJ) energy intake and multiple pregnancies, respectively. During recruitment, women could enter the study more than once, and by restricting our analyses to first pregnancy enrollment, an additional 6666 pregnancies were excluded. Additional exclusion of women with pre-existing diabetes resulted in the final DNBC dataset of 60,141 women.

The MoBa database contained information on 77,750 singleton pregnancies with available dietary information. Using the same energy restriction as for the DNBC, an additional 1221 pregnancies were excluded. Further restriction to first pregnancy enrollment $(n=9224)$ and exclusion of women with pre-existing diabetes $(n=1003)$ resulted in the final dataset of 66,302 women. The combined number of women available for analyses from both cohorts was 126,443 . See the flowchart in Supplemental Figure S1.

\subsection{Dietary Variables}

Considerations for merging the dietary variables of the participants from both cohorts have been described elsewhere [17]. In both cohorts, the FFQs were designed and validated specifically for pregnant women [18-21].

The FFQs gave portion sizes for units of fruit, bread (slices) and liquids (cups/glasses). However, to scale frequencies of intake into amounts $(\mathrm{g} / \mathrm{d})$, both cohorts used assumptions of standard Norwegian and Danish portion sizes for women, gathered from national dietary surveys. Based on these assumptions and by defining recipes for composite foods, the amount consumed for each food item in the FFQs was quantified in $\mathrm{g} /$ day. The amount of energy and nutrients from each food item was then estimated based on linkage to the National Food Composition Table. The total amount of energy (in MJ/day), protein (in $\mathrm{g}$ /day) and other nutrients was then estimated by aggregating the contribution from all food items.

Portion sizes used for protein-rich food were similar in the two FFQs and the same software for nutrient calculations was used. The timeframe for the two FFQs covered was, however, slightly different. In DNBC, the FFQ was administered in gestational week 25 and covered food intake over the previous four weeks, while in MoBa, the FFQ was administered in week 22 (week 17 up to 2004), covering food intake from the beginning of pregnancy.

\subsection{Outcome Variables}

Results from the Harlem Trial [1] suggested that high-protein supplementation may result in an excess risk of very early preterm deliveries, growth retardation up to week 37 of pregnancy and neonatal deaths. To address these outcomes, in our primary analyses, we examined associations between maternal protein intake and (1) birth weight as a continuous outcome among all infants and preterm (<37 weeks) infants only; (2) low birth weight $(<2500 \mathrm{~g}),(3)$ preterm delivery ( $<37$ weeks) and (4) fetal death, defined as death occurring after filling out the FFQ and until or during delivery; and (5) neonatal death, defined as offspring death occurring during the first 28 days of life. In our secondary analyses, associations with late (weeks 34 to $<37$ ), early (32 to <34 weeks) and very early (<32 weeks) preterm deliveries were also explored. 
Information on birth weight and fetal death was extracted from the national birth registries and information on neonatal death was obtained from national death registries in both countries. In MoBa, gestational age (in days) was primarily (98\%) based on the ultrasound measure from weeks 17 to 18 . When that information was missing, information on last menstrual period as reported by the women during pregnancy (2\%) was used. In DNBC, gestational age (in days) was assessed from the last menstrual period (43\%), based on maternal report at recruitment (week $\sim 6$ ) or in the first telephone interview (week 12). If this estimate was uncertain due to irregular or abnormal ( $>32$ or $<24$ days) menstrual cycles, gestational age was based on information on expected date of delivery (55\%) as reported by the women, which was most often based on ultrasound scanning. If this information was missing, gestational age as assessed at delivery by the midwife was used $(2 \%)$.

\subsection{Covariate Information}

The following set of covariates were selected a priori for adjusted models: cohort $(0 / 1)$, maternal age $(<20,20-24,25-29,30-34,35-39$ and $\geq 40$ years, no missing), parity $(1,2,3+, 2.3 \%$ missing), energy intake (in quintiles, no missing), pre-pregnancy BMI $(<18.5$, $18.5-24.9,25-29.9$ and $>30 \mathrm{~kg} / \mathrm{m}^{2}, 6.2 \%$ missing), maternal smoking during pregnancy (no, occasionally and daily smoking, 3.0\% missing), maternal education (less than basic studies, high school, college or higher education, 15.1\% missing), maternal height ( $<160$, 160-165, 166-175 and >175 cm, 4.8\% missing), maternal cohabitant status (single, nonsingle, $4.9 \%$ missing) and fetal sex (binary variable, $0.2 \%$ missing). Variables with missing values over $3 \%$ were assigned to a missing category and adjustments were made using dummy variables. However, if missing values were $<3 \%$, they were imputed using the mode from the variable's distribution. To account for potential confounding for energy intake, maternal protein intake was adjusted for energy using the residual method [22]. That is, protein intake of participants was regressed on their total energy intake. The residuals were then scaled using a constant corresponding to the predicted protein intake for the mean energy intake. These scaled residuals reflect individual variation in protein as predicted by energy intake. This approach is comparable to using nutrient densities but is more effective in accounting for potential confounding by energy.

\subsection{Statistical Analysis}

Continuous normally distributed variables were described using the mean and standard deviation (SD), while dichotomous variables were described using percentages. Associations with dichotomous and continuous outcomes were examined using multivariate logistic and linear regression analyses, respectively.

Maternal protein intake was divided into categories of $<60,60-70,>70-80,>80-90$, $>90-100$ and $>100 \mathrm{~g} /$ day. The most prevalent ( $34 \%$ of subjects) category of $>80-90 \mathrm{~g} /$ day protein was used as the reference. The highest protein category reflects similar intakes as reported in the high-protein supplementation group in the Harlem Trial [1]. As a test for overall effect, we used a chi-square test (type III) for dichotomous and F test (type III) for continuous variables, testing the null hypothesis that the response across groups was equal.

In our secondary analyses, we explored associations at more extreme protein intakes of $\geq 105, \geq 110,>115$ and $>120 \mathrm{~g} /$ day using the same reference as in the primary analyses. As the protein supplementation in the Harlem Trial was based on casein, we also explored associations between dairy protein (from milk, yoghurt, cheese and butter) with our primary outcomes separately. Finally, the stability of our preterm delivery estimates was examined by repeating our analyses using the gestational age estimate based on the date for last menstrual period that was partly available for both cohorts.

\section{Results}

The prevalence of preterm delivery, low birth weight and fetal and neonatal deaths was $4.77 \%, 2.93 \%, 0.28 \%$ and $0.17 \%$, respectively, with similar prevalence being observed 
in both cohorts (Table 1). Mean birth weight (SD) was $3591 \mathrm{~g}$ (566 g). Maternal characteristics were generally similar, except for maternal smoking, which differed substantially between the two cohorts. In both cohorts, energy (mean $10.0 \mathrm{MJ}$ ) and protein intakes (mean $89 \mathrm{~g} /$ day) were similar. On average, more than two thirds ( $60-70 \mathrm{~g} /$ day) of dietary protein came from animal sources, with the intake of proteins from dairy being relatively high ( $\sim 30 \mathrm{~g} /$ day). After adjusting for energy [22], the overall protein distribution used in our analyses was 68, 79, 87, 103 and $109 \mathrm{~g} /$ day for the 5th, 25th, 50th, 75th and 95th percentiles, respectively.

Table 1. Characteristics of participants in the Danish National Birth Cohort (DNBC, 1996-2002) and the Norwegian Mother, Father and Child Cohort study (MoBa, 2002-2008).

\begin{tabular}{|c|c|c|c|}
\hline & $\begin{array}{c}\text { DNBC } \\
n=60,141\end{array}$ & $\begin{array}{c}\text { MoBa } \\
n=66,302\end{array}$ & $\begin{array}{l}\text { Combined } \\
n=126,443\end{array}$ \\
\hline \multicolumn{4}{|l|}{ Maternal Characteristics } \\
\hline Age, years & $30.3(4.2)$ & $30.7(4.6)$ & $30.5(4.4)$ \\
\hline Pre-pregnancy BMI, $\mathrm{kg} / \mathrm{m}^{2}$ & $23.5(4.2)$ & $24.1(4.3)$ & $23.8(4.2)$ \\
\hline$<18.5$ & 4.0 & 2.8 & 3.8 \\
\hline $18.5-24.9$ & 64.4 & 61.2 & 62.7 \\
\hline $25-29.9$ & 18.2 & 20.8 & 19.5 \\
\hline$>30$ & 7.2 & 8.9 & 8.1 \\
\hline Missing & 6.1 & 6.3 & 6.3 \\
\hline Height $(\mathrm{cm})$ & $169(6)$ & $168(6)$ & $168(6)$ \\
\hline \multicolumn{4}{|l|}{ Education, \% } \\
\hline Less than basic studies & 0.2 & 6.6 & 3.6 \\
\hline High school & 24.0 & 24.0 & 24.1 \\
\hline College or higher education & 50.4 & 63.4 & 57.1 \\
\hline Missing & 25.4 & 5.8 & 15.2 \\
\hline \multicolumn{4}{|l|}{ Marital status, \% } \\
\hline Married & 93.5 & 92.6 & 93.0 \\
\hline Unmarried & 1.8 & 2.2 & 2.0 \\
\hline \multirow{2}{*}{\multicolumn{4}{|c|}{ Smoking, \% }} \\
\hline & & & \\
\hline Non-smoker & 74.1 & 87.5 & 85.4 \\
\hline Occasional smoker & 12.6 & 2.7 & 6.0 \\
\hline Smokes daily & 12.3 & 5.3 & 5.8 \\
\hline Missing & 1.0 & 4.5 & 2.8 \\
\hline \multicolumn{4}{|l|}{ Parity, \% } \\
\hline 0 & 55.2 & 46.7 & 50.7 \\
\hline 1 & 31.1 & 34.7 & 33.0 \\
\hline 2 & 11.3 & 15.0 & 13.3 \\
\hline $3+$ & 2.4 & 3.6 & 3.0 \\
\hline Energy intake (MJ/d) & $10.0(2.5)$ & $9.7(2.6)$ & $9.9(2.6)$ \\
\hline Protein intake (\% of Energy) & $15.7(2.4)$ & $15.4(2.1)$ & $15.6(2.3)$ \\
\hline Protein intake (g/day) & $92(24)$ & $87(21)$ & $89(23)$ \\
\hline Animal protein (g/day) & 60 (19) & $72(20)$ & $66(21)$ \\
\hline As dairy protein (g/day) & $30(15)$ & $30(17)$ & $30(16)$ \\
\hline Plant protein (g/day) & $32(9)$ & 15 (12) & $23(13)$ \\
\hline Total fat intake (g/day) & $84(31)$ & $80(25)$ & $82(28)$ \\
\hline Carbohydrates (g/day) & $330(87)$ & $310(93)$ & $320(91)$ \\
\hline \multicolumn{4}{|l|}{ Obstetric outcomes } \\
\hline Birth weight $(\mathrm{g})$ & $3587(560)$ & $3583(555)$ & $3591(566)$ \\
\hline Preterm delivery (<37 weeks), \% & 4.60 & 4.92 & 4.77 \\
\hline Low birth weight $(<2500 \mathrm{~g}), \%$ & 2.85 & 3.01 & 2.93 \\
\hline Fetal death, $\%$ & 0.31 & 0.26 & 0.28 \\
\hline Neonatal death, $\%$ & 0.19 & 0.16 & 0.17 \\
\hline
\end{tabular}

Offspring of mothers with low protein intake ( $<60 \mathrm{~g} /$ day) had around $130 \mathrm{~g}$ lower birth weight compared to offspring whose mothers had modest (80-90 g/day) intake (Table 2). At higher maternal intakes (up to $>100 \mathrm{~g} /$ day), no meaningful differences in birth weight were observed compared to mothers with modest (80-90 g/day) intakes. A similar pattern was observed when examining preterm ( $<37$ weeks) infants only. 
Table 2. Associations between maternal protein intake and birth weight for all births and for preterm ( $<37$ weeks) births only. Mean differences $(\Delta)$ in birth weight across categories of protein intake relative to the reference (80-90 g) category are shown. The Danish National Birth Cohort (DNBC, 1996-2002) and the Norwegian Mother, Father and Child Cohort Study (MoBa, 2002-2008).

\begin{tabular}{|c|c|c|c|c|}
\hline & \multicolumn{2}{|c|}{ All Births $(N=125,573)$} & \multicolumn{2}{|c|}{ Preterm $(<37$ Weeks) Only $(N=5898)$} \\
\hline & Unadjusted & Adjusted ${ }^{1}$ & Unadjusted & Adjusted ${ }^{1}$ \\
\hline Protein $^{2}$ & $\Delta \underset{(95 \% \mathrm{CI})}{\Delta(\text { in Grams) }}$ & $\underset{(95 \% \mathrm{CI})}{\Delta \text { (in Grams) }}$ & $\underset{(95 \% \mathrm{CI})}{\Delta(\text { in Grams) }}$ & $\underset{(95 \% \mathrm{CI})}{\Delta(\text { in Grams) }}$ \\
\hline $\begin{array}{c}<60 \mathrm{~g} \\
60-70 \mathrm{~g} \\
70-80 \mathrm{~g} \\
80-90 \mathrm{~g} \\
90-100 \mathrm{~g} \\
>100 \mathrm{~g} \\
p \text { for effect }^{3}\end{array}$ & $\begin{array}{c}-127(-157,-97) \\
-44(-59,-31) \\
-16(-25,-8) \\
\text { Referent } \\
9(1,17) \\
7(-2,17) \\
<0.0001\end{array}$ & $\begin{array}{c}-51(-74,-28) \\
-20(-31,-10) \\
-6(-13,0) \\
\text { Referent } \\
9(3,15) \\
18(10,25) \\
<0.0001\end{array}$ & $\begin{array}{c}-234(-391,-76) \\
9(-69,89) \\
-4(-54,46) \\
\text { Referent } \\
43(-5,90) \\
54(-1,111) \\
0.005\end{array}$ & $\begin{array}{c}-128(-230,-27) \\
28(-22,79) \\
9(-23,40) \\
\text { Referent } \\
35(4,66) \\
31(-6,67) \\
0.01\end{array}$ \\
\hline
\end{tabular}

$\Delta:$ mean difference in birth weight in grams per day compared to the reference. ${ }^{1}$ Adjusted for cohort, maternal age, parity, maternal smoking, pre-pregnancy body mass index, height, education, marital status, total energy intake and gestational age. ${ }^{2}$ Across categories from low $(<60 \mathrm{~g})$ to high $(>100 \mathrm{~g})$ protein intakes, the corresponding median (10th-90th percentiles) protein intake relative to body weight (in g/ kg) was $0.9(0.6-1.1), 1.0(0.8-1.3)$, $1.2(0.9-1.4), 1.3(1.0-1.6), 1.4(1.1-1.7)$ and $1.6(1.2-2.0)$, respectively. ${ }^{3} \mathrm{~F}$ test type III.

In unadjusted analyses, the association between maternal protein intake and preterm delivery (Table 3) was U-shaped with an OR of 1.31 (95\%CI: 1.04, 1.64) for preterm delivery in those with low intake ( $<60 \mathrm{~g} /$ day) and an increased OR of 1.11 (95\%CI: 1.02, 1.21) for those with high (>100 g) compared to moderate (80-90 g/day) intake. After adjustment for covariates, the effect estimate for low ( $<60 \mathrm{~g} /$ day) intake was attenuated and nonsignificant but a similar and significant increased risk of 1.10 (95\%CI: 1.01, 1.19) was still observed for high protein (>100 g/day) compared to moderate protein (80-90 g/day) intake. High (>100 g/day) protein intake was also not associated with low birth weight, while increased risk was observed at low protein intake ( $<60 \mathrm{~g} /$ day). Overall, the effect estimates for preterm delivery and low birth weight were similar in both cohorts (Supplemental Table S1). When stratifying by pre-pregnancy $\left(<25\right.$ and $\left.\geq 25 \mathrm{~kg} / \mathrm{m}^{2}\right)$, similar associations between protein intake and preterm delivery and low birth weight were also observed in both strata (Supplimental Table S2).

Table 3. Associations between maternal protein intake and risk of preterm delivery and low birth weight. The associations are presented in terms of odds ratios (ORs) using the 80-90 g category as the reference. The Danish National Birth Cohort (DNBC, 1996-2002) and the Norwegian Mother, Father and Child Cohort study (MoBa, 2002-2008).

\begin{tabular}{|c|c|c|c|}
\hline & & Unadjusted & Adjusted $^{1}$ \\
\hline Protein $^{2}$ & Cases $(\%) / \mathbf{N}$ & OR $(95 \% C I)$ & OR $(95 \% C I)$ \\
\hline$N=126,144$ & & \multicolumn{2}{|c|}{ Preterm delivery $(<37$ weeks) } \\
\hline$<60 \mathrm{~g}$ & $81(5.9 \%) / 1378$ & $1.31(1.04,1.64)$ & $1.17(0.93,1.47)$ \\
\hline $60-70 \mathrm{~g}$ & $365(5.0 \%) / 7280$ & $1.10(0.98,1.24)$ & $1.06(0.94,1.19)$ \\
\hline $70-80 \mathrm{~g}$ & $1283(4.9 \%) / 26,034$ & $1.08(1.01,1.16)$ & $1.07(1.00,1.15)$ \\
\hline $80-90 \mathrm{~g}$ & $1949(4.6 \%) / 42,674$ & 1.00 & 1.00 \\
\hline $90-100 \mathrm{~g}$ & $1454(4.7 \%) / 31,257$ & $1.02(0.95,109)$ & $1.02(0.95,1.10)$ \\
\hline$>100 \mathrm{~g}$ & $884(5.1 \%) / 17,521$ & $1.11(1.02,1.21)$ & $1.10(1.01,1.19)$ \\
\hline$p$ for effect ${ }^{3}$ & $\left(\chi^{2}\right.$, type III $)$ & 0.02 & 0.18 \\
\hline$N=125,624$ & & \multicolumn{2}{|c|}{ Low birth weight $(<2.5 \mathrm{~kg})$} \\
\hline$<60 \mathrm{~g}$ & $75(5.5 \%) / 1368$ & $1.97(1.55,2.50)$ & 1.59 (1.25 2.03) \\
\hline $60-70 \mathrm{~g}$ & $264(3.6 \%) / 7253$ & $1.28(1.12,1.47)$ & $1.17(1.02,1.34)$ \\
\hline $70-80 \mathrm{~g}$ & $778(3.0 \%) / 25,944$ & $1.05(0.96,1.15)$ & $1.02(0.93,1.12)$ \\
\hline $80-90 \mathrm{~g}$ & $1219(2.9 \%) / 42,536$ & 1.00 & 1.00 \\
\hline $90-100 \mathrm{~g}$ & $839(2.7 \%) / 31,092$ & $0.94(0.86,1.03)$ & $0.95(0.87,1.04)$ \\
\hline$>100 \mathrm{~g}$ & $508(2.9 \%) / 17,431$ & $1.02(0.92,1.13)$ & $1.01(0.90,1.12)$ \\
\hline$p$ for effect $^{3}$ & $\left(\chi^{2}\right.$, type III $)$ & $<0.0001$ & 0.0005 \\
\hline
\end{tabular}

${ }^{1}$ Adjusted for cohort, age, parity, maternal smoking, pre-pregnancy body mass index, height, education, marital status, infant sex and total energy intake. ${ }^{2}$ Across categories from low $(<60 \mathrm{~g})$ to high $(>100 \mathrm{~g})$ protein intakes, the corresponding median (10th-90th percentiles) protein intake relative to body weight (in $\mathrm{g} / \mathrm{kg}$ ) was $0.9(0.6-1.1)$, $1.0(0.8-1.3), 1.2(0.9-1.4), 1.3(1.0-1.6), 1.4(1.1-1.7)$ and $1.6(1.2-2.0)$, respectively. ${ }^{3} \mathrm{~F}$ test type III. 
As secondary analyses, we also examined the association with birth weight and preterm delivery at more extreme protein intakes. Compared to moderate protein intake (80-90 g), no indication of reduced birth weight among all infants or preterm infants only was observed at intakes as high as $>120 \mathrm{~g}$ (Table 4 ).

Table 4. Extreme protein intake in relation to birth weight among all infants and preterm infants only. Mean differences $(\Delta)$ in birth weight across categories of protein intake relative to the reference (80-90 g) category are shown. The Danish National Birth Cohort (DNBC, 1996-2002) and the Norwegian Mother, Father and Child Cohort study (MoBa, 2002-2008).

\begin{tabular}{|c|c|c|c|c|}
\hline \multirow[b]{2}{*}{ Protein $^{2}$} & \multicolumn{2}{|c|}{ All Births $(N=125,573)^{1}$} & \multicolumn{2}{|c|}{ Preterm (<37 Weeks) Only $(N=5898)^{1}$} \\
\hline & $\begin{array}{c}\text { No. Referent/No. } \\
\text { High }\end{array}$ & $\Delta$ (in Grams) $(95 \% \mathrm{CI})$ & $\begin{array}{l}\text { No. Referent/No. } \\
\text { High }\end{array}$ & $\Delta$ (in Grams) $(95 \% \mathrm{CI})$ \\
\hline 80-90 g vs. $>100 \mathrm{~g}$ & 42,593 vs. 17,455 & $18(10,25)$ & $1919 / 864$ & $31(-6,67)$ \\
\hline 80-90 g vs. >105 g & 42,593 vs. 9428 & $16(6,26)$ & $1919 / 482$ & $38(-9,82)$ \\
\hline $80-90 \mathrm{~g}$ vs. $>110 \mathrm{~g}$ & 42,593 vs. 4842 & $10(-3,22)$ & $1919 / 224$ & $44(-16,105)$ \\
\hline $80-90 \mathrm{~g}$ vs. $>115 \mathrm{~g}$ & 42,593 vs. 2319 & $22(5,41)$ & $1919 / 114$ & $94(9,180)$ \\
\hline $80-90 \mathrm{~g}$ vs. $>120 \mathrm{~g}$ & 42,593 vs. 1086 & $13(-12,39)$ & $1919 / 59$ & $99(-17,216)$ \\
\hline
\end{tabular}

$\Delta$ : mean difference in birth weight in grams per day compared to the reference. ${ }^{1}$ Adjusted for cohort, maternal age, parity, maternal smoking, pre-pregnancy body mass index, height, education, marital status, total energy intake and gestational age. ${ }^{2}$ Protein intake (median (10th-90th percentiles)) relative to body weight (in g/ $\mathrm{kg}$ ) was $1.3(1.0-1.6)$ in the 80-90 g group; $1.6(1.2-2.0)$ in the $>100 \mathrm{~g}$ group; $1.7(1.3-2.0)$ in the $>105$ g group; $1.7(1.3-2.1)$ in the $>110 \mathrm{~g}$ group; $1.8(1.4-2.2)$ in the $>115$ g group; and $1.9(1.4-2.3)$ in the $>120 \mathrm{~g}$ group.

The effect estimates for preterm delivery at high protein intake (see Table 3) were also stable around 1.10 at intakes up to $>120 \mathrm{~g} /$ day (Table 5) and a non-significant increase in risk of low birth weight was observed at these high intakes.

Table 5. Extreme protein intake in relation to preterm birth and low birth weight. The associations are presented in terms of odds ratios (ORs) using the 80-90 g category as the reference. The Danish National Birth Cohort (DNBC, 1996-2002) and the Norwegian Mother, Father and Child Cohort study (MoBa, 2002-2008).

\begin{tabular}{|c|c|c|c|c|}
\hline \multirow[b]{2}{*}{ Protein $^{2}$} & \multicolumn{2}{|c|}{ Preterm Delivery (<37 Weeks) ${ }^{1}$} & \multicolumn{2}{|c|}{ Low Birth Weight $(<2.5 \mathrm{~kg})^{1}$} \\
\hline & N/Cases (\%) & OR $(95 \% \mathrm{CI})$ & N/Cases (\%) & OR $(95 \% \mathrm{CI})$ \\
\hline $80-90$ g vs. $>100 \mathrm{~g}$ & $\begin{array}{c}42,674 / 1949(4.6 \%) \\
\text { vs. } 17,521 / 884(5.1 \%)\end{array}$ & $1.10(1.01,1.19)$ & $\begin{array}{c}42,536 / 1219(2.9 \%) \\
\text { vs. } 17,431 / 508(2.9 \%)\end{array}$ & $1.01(0.90,1.12)$ \\
\hline $80-90$ g vs. $>105$ g & $\begin{array}{c}42,674 / 1949(4.6 \%) \\
\text { vs. } 9474 / 499(5.3 \%)\end{array}$ & $1.14(1.03,1.27)$ & $\begin{array}{c}42,536 / 1219(2.9 \%) \\
\text { vs. } 9417 / 286(3.0 \%)\end{array}$ & $1.04(0.91,1.19)$ \\
\hline $80-90$ g vs. $>110 \mathrm{~g}$ & $\begin{array}{c}42,674 / 1949(4.6 \%) \\
\text { vs. } 4872 / 255(5.2 \%)\end{array}$ & $1.13(0.98,1.29)$ & $\begin{array}{c}42,536 / 1219(2.9 \%) \\
\text { vs. } 4835 / 149(3.1 \%)\end{array}$ & $1.05(0.89,1.25)$ \\
\hline $80-90$ g vs. $>115 \mathrm{~g}$ & $\begin{array}{c}42,674 / 1949(4.6 \%) \\
\text { vs. } 2342 / 120(5.1 \%)\end{array}$ & $1.09(0.89,1.31)$ & $\begin{array}{l}42,536 / 1219(2.9 \%) \\
\text { vs. } 2317 / 71(3.1 \%)\end{array}$ & $1.02(0.80,1.31)$ \\
\hline $80-90$ g vs. $>120 \mathrm{~g}$ & $\begin{array}{l}42,674 / 1949(4.6 \%) \\
\text { vs. } 1094 / 59(5.4 \%)\end{array}$ & $1.13(0.86,1.47)$ & $\begin{array}{l}42,536 / 1219(2.9 \%) \\
\text { vs. } 1086 / 32(3.0 \%)\end{array}$ & $0.95(0.66,1.35)$ \\
\hline
\end{tabular}

${ }^{1}$ Adjusted for cohort, maternal age, parity, maternal smoking, pre-pregnancy body mass index, height, education, marital status, infant sex and total energy intake. ${ }^{2}$ Protein intake (median (10th-90th percentiles)) relative to body weight (in $\mathrm{g} / \mathrm{kg}$ ) was 1.3 (1.0-1.6) in the 80-90 g group; $1.6(1.2-2.0)$ in the $>100$ group; $1.7(1.3-2.0)$ in the $>105$ g group; $1.7(1.3-2.1)$ in the $>110$ g group; $1.8(1.4-2.2)$ in the $>115$ g group; and $1.9(1.4-2.3)$ in the $>120$ g group.

Maternal protein intake was not associated with fetal death or neonatal death (Table 6, $\mathrm{p}$ for effect $>0.20$ in all cases). A non-significant decreased risk of fetal death was observed at high (>100 g) vs. modest (80-90 g/day) protein intakes [OR: 0.70 (95\%CI: 0.48, 1.01)], but this estimate was driven by the significantly reduced risk observed in DNBC only [OR: 0.21 (95\%CI: 0.07, 0.61)], not MoBa (OR: 0.92 (95\%CI: 0.52, 1.65)), which points towards a chance finding. 
Table 6. Associations between maternal protein intake and risk of fetal and neonatal deaths. The associations are presented in terms of odds ratios (ORs) using the 80-90 g category as the reference. The Danish National Birth Cohort (DNBC, 1996-2002) and the Norwegian Mother, Father and Child Cohort study (MoBa, 2002-2008).

\begin{tabular}{cccc}
\hline & & Unadjusted & Adjusted \\
\hline Protein $^{2}$ & Cases $\mathbf{~} \%) / \mathbf{N}$ & OR (95\%CI) & OR (95\%CI) \\
\hline$N=126,443$ & & \multicolumn{2}{c}{ Fetal death } \\
\hline$<60 \mathrm{~g}$ & $3(0.22 \%) / 1381$ & $0.73(0.23,2.30)$ & $0.78(0.24,2.58)$ \\
$60-70 \mathrm{~g}$ & $16(0.22 \%) / 7301$ & $0.74(0.44,1.24)$ & $0.88(0.51,1.52)$ \\
$70-80 \mathrm{~g}$ & $79(0.30 \%) / 26,110$ & $1.02(0.77,1.35)$ & $1.18(0.88,1.58)$ \\
$80-90 \mathrm{~g}$ & $127(0.30 \%) / 42,782$ & 1.00 & 1.00 \\
$90-100 \mathrm{~g}$ & $95(0.30 \%) / 31,314$ & $1.02(0.78,1.33)$ & $1.02(0.77,1.35)$ \\
$>100 \mathrm{~g}$ & $40(0.23 \%) / 17,555$ & $0.77(0.54,1.10)$ & $0.70(0.48,1.01)$ \\
$p$ for effect $^{3}$ & $\left(\chi^{2}\right.$, type III) & 0.52 & 0.22 \\
\hline$N=126,081$ & & \multicolumn{2}{c}{ Neonatal death } \\
\hline$<60 \mathrm{~g}$ & $1(0.01 \%) / 1378$ & $0.47(0.07,3.38)$ & $0.41(0.06,2.99)$ \\
$60-70 \mathrm{~g}$ & $18(0.27 \%) / 7285$ & $1.59(0.95,2.69)$ & $1.54(0.91,2.61)$ \\
$70-80 \mathrm{~g}$ & $45(0.17 \%) / 26,031$ & $1.12(0.77,1.63)$ & $1.14(0.78,1.66)$ \\
$80-90 \mathrm{~g}$ & $66(0.15 \%) / 42,655$ & 1.00 & 1.00 \\
$90-100 \mathrm{~g}$ & $56(0.18 \%) / 31,217$ & $1.16(0.81,1.66)$ & $1.12(0.78,1.60)$ \\
$>100 \mathrm{~g}$ & $34(0.19 \%) / 17,515$ & $1.26(0.83,1.90)$ & $1.11(0.73,1.70)$ \\
$p$ for effect $^{3}$ & $\left(\chi^{2}\right.$, type III) & 0.40 & 0.61 \\
\hline
\end{tabular}

${ }^{1}$ Adjusted for cohort, age, parity, maternal smoking, pre-pregnancy body mass index, height, education, marital status, infant sex and total energy intake. ${ }^{2}$ Across categories from low $(<60 \mathrm{~g})$ to high $(>100 \mathrm{~g})$ protein intakes, the corresponding median (10th-90th percentiles) protein intake relative to body weight (in g/ kg) was 0.9 (0.6-1.1), $1.0(0.8-1.3), 1.2(0.9-1.4), 1.3(1.0-1.6), 1.4(1.1-1.7)$ and $1.6(1.2-2.0)$, respectively. ${ }^{3} \mathrm{~F}$ test type III.

Additional and more exploratory analyses also showed that the association for preterm delivery was driven by late ( $\geq 34$ to $<37$ weeks), but not early ( $\geq 32$ to $<34$ weeks) or very early ( $<32$ weeks) preterm, delivery. The effect estimates on preterm delivery were not sensitive to the use of ultrasound vs. date of last menstrual period. We also examined the associations between intake of dairy protein (milk, yoghurt, cheese and butter) and preterm delivery. Overall, these were similar to the results for total proteins, but the effect estimate for preterm delivery was slightly stronger [OR: 1.17 (95\%CI: 1.05, 1.30)] when examining very high intake of dairy proteins ( $>50 \mathrm{~g}, \sim 7 \%$ having intake at that level) vs. more moderate intake (20-30 g/day, 31\% having intake at that level).

\section{Discussion}

Contrary to previous findings from a randomized dietary intervention from the 1970s on high-protein supplementation in pregnancy [1], which has since influenced reviews on this subject and dietary recommendations [2-7], we found no indications of increased risk of growth restrictions or fetal and neonatal deaths at high protein intakes. High protein intake was modestly associated with risk of preterm delivery.

Preterm deliveries and low birth weight are risk factors for both perinatal mortality and morbidity as well as later physical and mental disabilities [23-25]. While protein is crucial for optimal intrauterine growth and development, the optimal range is less known. In the Harlem Trial [1], the supplement consisted of $40 \mathrm{~g}$ of protein in the form of casein. This amount is equivalent to $\sim 1.4 \mathrm{~L}$ of cow's milk, corresponding to around half the recommended protein intake for the pregnant women in our study population [4]. The supplementation in the Harlem Trial came out on top of the habitual protein intake, corresponding to $100 \mathrm{~g}$ in total. The supplementation also included a number of vitamins and minerals, which were, with the exception of retinol (6000 retinol equivalents), well below the upper intake (UI) limits [4]. The supplementation may have been unbeneficial for all of the Harlem Trial outcomes and could relate to more than high protein intake only, such as specific effects of the protein type, casein, or combined effects of high protein 
and, e.g., retinol. Although speculative, a modest adverse effect of the supplementation may have, in the 1970s, also produced worse outcomes, in terms of offspring survival, than would occur in today's setting with routine antenatal and ultrasound scanning that captures fetuses at risk, providing further monitoring and intervention. In light of our results, the role of a chance finding in the Harlem Trial also appears plausible.

The effect size of our finding for preterm birth was modest and its relevance should be subject to careful interpretation. It is, however, worth noting that our estimate for high intake [OR: $1.10(1.01,1.19)]$ was of similar magnitude as the effect estimate of preterm delivery in the Harlem Trial [relative risk of 1.14 (95\%CI: $0.83 ; 1.56)$ ], as synthesized from the original data [2]. Higher risk of preterm delivery has also been reported in a recent prospective Chinese study among subjects with relatively high intake of protein from dairy [26]. Regarding the possible mechanism by which protein intake might affect the length of gestation, previous studies have found that protein, especially from animal sources, is related to higher levels of inflammatory markers in serum during pregnancy $[27,28]$, a condition that has been related to higher risk of preterm delivery $[29,30]$.

The lower mean birth weight and increased risk of having low-birth weight infants observed among women with protein intake below $60 \mathrm{~g}$ /day in our study are in line with previous interventions showing beneficial effects of balanced protein supplementation in undernourished populations [2]. Standardized for weight, the women in the $<60 \mathrm{~g} /$ day protein group in our study had a median intake of $0.87 \mathrm{~g} / \mathrm{kg}$ body weight per day. The estimated average requirement for pregnant women according to the Institute of Medicine is $0.88 \mathrm{~g} / \mathrm{kg}$ body weight per day, which is the lowest level of intake needed to account for losses of nitrogen from the body. There are some recent suggestions that the average protein requirements for pregnant women are somewhat higher [31], particularly in late gestation. In this context, it appears likely that some of the women in our low-protein group ( $<60 \mathrm{~g} /$ day) may have had insufficient intake to support optimal fetal growth.

Our study has several strengths. Firstly, the prospective design and large statistical power made it possible to examine associations with rare obstetric outcomes with some precision. The sample size of each cohort also allowed us to explore the stability of our findings separately in each country. This was important, as dietary and certain lifestyle habits (including smoking) are known to differ between the two countries and reproducing the estimate in two independent settings allows for more robust conclusions. Our outcome variables were extracted from national birth registries which use standard procedures for registration and where in-house quality is constantly monitored.

Concerning limitations, the fact that our study is observational means that we cannot rule out the influence of unadjusted confounder(s) and residual confounding. Another limitation is that the dietary assessment in the two cohorts did not cover the complete pregnancy period. However, studies with repeated dietary assessment have shown that dietary habits in pregnancy remain relatively stable [32,33]. With respect to the interpretation of our findings, a direct comparison between our study results and those reported in the Harlem Trial is hampered by important differences in the two study populations and study design. The women recruited into the Harlem Trial were recruited from a poor black African American community and those eligible for inclusion had to have at least one of the following risk factors for having a low-birth weight infant: (1) low pre-pregnancy weight ( $<110$ pounds), (2) low weight gain at the time of recruitment, (3) at least one previous low-birth weight infant and (4) protein intake of $<50 \mathrm{~g}$ as derived from one 24 -h dietary recall. Relatively few women in our well-nourished Nordic population would have met one or more of these conditions. In addition, our study examined dietary, but not supplemental, protein, and these two ways of consumption have important differences. For example, high dietary protein intake from foods of animal origin is associated with higher intake of fats and certain minerals and vitamins including vitamin B6, B12, iron and zinc. High intake of proteins from plant sources is, however, usually associated with higher intake of carbohydrates and fibers and a different micronutrient profile. Our dietary intake estimates also reflect aggregated protein intake over the whole day. In contrast, protein 
supplementation usually means consumption of proteins largely in the absence of other macronutrients, and much larger amounts of proteins can be consumed as supplements in liquid form over a short period compared to normal dietary intake, which may have induced more metabolic strain [34]. In summary, given these important differences, the null findings from our Nordic study population do not reject the possibility that the effect of high-protein supplementation in the Harlem Trial had deleterious effects on fetal growth and neonatal mortality in that low-income, high-risk population [1].

\section{Conclusions}

In contrast to the results from the Harlem Trial, the results from this large prospective study, conducted in a well-nourished population, do not support a link between high dietary intake of proteins in pregnancy and growth retardation and fetal or neonatal deaths. However, in line with the results of the Harlem Trial, we found a modest, but significantly increased, risk of preterm delivery. Taken together, existing evidence suggests that for healthy pregnant women, high-protein diets have no clear benefits, and care should be taken before advocating extremely high intakes.

Supplementary Materials: The following are available online at https://www.mdpi.com/2072-6 $643 / 13 / 2 / 440 / s 1$, Figure S1: Flowchart for inclusion of participants in the combined study from the two cohorts: Danish National Birth Cohort (DNBC) and the Norwegian Mother, Father and Child Cohort (MoBa), Table S1: Maternal protein intake in relation to preterm delivery and low birth weight in the Danish National Birth Cohort (1996-2002) and the Norwegian Mother, Father and Child Cohort study (2002-2008). Table S2. Associations between maternal protein intake and risk of preterm delivery and low birth weight stratified by pre-pregnancy body mass index.

Author Contributions: The idea behind this study was conceived during an expert working group meeting in connection with developing the Nordic Nutrition Recommendations, resulting in conceptualization by A.L.B., A.S.O., I.T. and S.F.O., T.I.H., B.E.B., A.L.B., H.M.M., M.H. and S.F.O. coined the methodology and visualization. T.I.H. was in charge of software and conducted the statistical and formal analysis. B.E.B., S.F.O. and A.S.O. conducted the validation and data curation. B.E.B. and T.I.H. conducted the original draft preparation with input from A.S.O. and I.T., S.F.O. and H.M.M. had the overall responsibility for the investigation, i.e., collection of dietary data in the DNBC and MoBa, respectively, as well as resources, supervision, funding acquisition and project administration. THI was responsible for the dietary database in DNBC, while A.L.B. and M.H. had the same role within MoBa. S.F.O., T.I.H., B.E.B., A.L.B., H.M.M. and M.H. worked on harmonizing the dietary components in the two cohorts that has made this work possible. All authors contributed to writing, i.e., interpreting the results, and to revising and reviewing the paper critically for intellectual content. All authors have read and agreed to the published version of the manuscript.

Funding: The Norwegian Mother, Father and Child Cohort Study is supported by the Norwegian Ministry of Health and Care Services and the Ministry of Education and Research. The Danish National Birth Cohort Study has been supported by the March of Dimes Birth Defects Foundation (6-FY-96-0240, 6-FY97-0553, 6-FY97-0521, 6-FY00-407), the Danish Heart Association, Danish Medical Research Council, Sygekassernes Helsefond and the Danish National Research Foundation. This coordinated analysis has been supported by Innovation Fund Denmark (grant No 09-067124, Centre for Fetal Programming) and Kræftens Bekæmpelse (R204-A12638).

Institutional Review Board Statement: The study was conducted according to the guidelines of the Declaration of Helsinki. The establishment and data collection in MoBa were previously based on a license from the Norwegian Data Protection Agency and approval from The Regional Committee for Medical Research Ethics (S-95113/S-97045). They are now based on regulations related to the Norwegian Health Registry Act. The regional scientific ethics committee for the municipalities of Copenhagen and Frederiksberg approved all DNBC study protocols (27 August 2013: H-2-2013-108). All procedures were in accordance with the Declaration of Helsinki.

Informed Consent Statement: Written informed consent was obtained from all participants in both cohorts. 
Data Availability Statement: The consent given by the participants does not open for storage of data on an individual level in repositories or journals. Researchers who want access to data sets for replication should submit an application. Access to data sets requires approval from ethical committees and an agreement with the cohorts.

Acknowledgments: We are grateful to all the participating families in Norway and Denmark who take part in these ongoing cohort studies.

Conflicts of Interest: The authors declare no conflict of interest. The funders had no role in the design of the study; in the collection, analyses, or interpretation of data; in the writing of the manuscript, or in the decision to publish the results.

\section{References}

1. Rush, D.; Stein, Z.; Susser, M. A randomized controlled trial of prenatal nutritional supplementation in New York City. Pediatrics 1980, 65, 683-697.

2. Ota, E.; Hori, H.; Mori, R.; Tobe-Gai, R.; Farrar, D. Antenatal dietary education and supplementation to increase energy and protein intake. Cochrane Database Syst. Rev. 2015, 6. [CrossRef] [PubMed]

3. World Health Organization (WHO). WHO Recommendations on Antenatal Care for a Positive Pregnancy Experience: Summary; Licence: CC BY-NC-SA 3.0 IGO; WHO: Geneva, Switzerland, 2018. Available online: https://apps.who.int/iris/bitstream/handle/10665/ 250796/9789241549912-websupplement-eng.pdf?sequence=8; https: / / extranet.who.int/rhl/topics / preconception-pregnancychildbirth-and-postpartum-care/antenatal-care/who-recommendation-high-protein-supplements-during-pregnancy (accessed on 5 May 2019).

4. Recommendations, N.N. Nordic Nutrition Recommendations 2012. In Integrating Nutrition and Physical Activity; Nordic Council of Ministers: Copenhagen, Denmark, 2014.

5. da Silva Lopes, K.; Ota, E.; Shakya, P.; Dagvadorj, A.; Balogun, O.O.; Peña-Rosas, J.P.; De-Regil, L.M.; Mori, R. Effects of nutrition interventions during pregnancy on low birth weight: An overview of systematic reviews. BMJ Glob. Health 2017, 2, e000389. [CrossRef] [PubMed]

6. Elango, R.; Ball, R.O. Protein and Amino Acid Requirements during Pregnancy. Adv. Nutr. 2016, 15, 839S-844S. [CrossRef] [PubMed]

7. Visser, J.; McLachlan, M.H.; Maayan, N.; Garner, P. Community-based supplementary feeding for food insecure, vulnerable and malnourished populations-An overview of systematic reviews. Cochrane Database Syst. Rev. 2018, 11, CD010578. [CrossRef] [PubMed]

8. Sloan, N.L.; Lederman, S.A.; Leighton, J.; Himes, J.H.; Rush, D. The effect of prenatal dietary protein intake on birth weight. Nutr. Res. 2001, 21, 129-139. [CrossRef]

9. Andreasyan, K.; Ponsonby, A.L.; Dwyer, T.; Morley, R.; Riley, M.; Dear, K.; Cochrane, J. Higher maternal dietary protein intake in late pregnancy is associated with a lower infant ponderal index at birth. Eur. J. Clin. Nutr. 2007, 61, 498-508. [CrossRef]

10. Morisaki, N.; Nagata, C.; Yasuo, S.; Morokuma, S.; Kato, K.; Sanefuji, M.; Shibata, E.; Tsuji, M.; Senju, A.; Kawamoto, T.; et al. Optimal protein intake during pregnancy for reducing the risk of fetal growth restriction: The Japan Environment and Children's Study. Br. J. Nutr. 2018, 120, 1432-1440. [CrossRef]

11. Kosinski, C.; Jornayvaz, F.R. Effects of Ketogenic Diets on Cardiovascular Risk Factors: Evidence from Animal and Human Studies. Nutrients 2017, 9, 517. [CrossRef]

12. Katz, D.L. The Truth About Food: Why Pandas Eat Bamboo and People Get Baboozled; Dystel \& Goderich: New York, NY, USA, 2018.

13. Olsen, J.; Melbye, M.; Olsen, S.F.; Sørensen, T.I.; Aaby, P.; Nybo Andersen, A.M.; Taxbøl, D.; Hansen, K.D.; Juhl, M.; Schow, T.B.; et al. The Danish National Birth Cohort-its background, structure and aim. Scand. J. Public Health 2001, 29, 300-307. [CrossRef] [PubMed]

14. Magnus, P.; Birke, C.; Vejrup, K.; Haugan, A.; Alsaker, E.; Daltveit, A.K.; Handal, M.; Haugen, M.; Høiseth, G.; Knudsen, G.P.; et al. Cohort Profile Update: The Norwegian Mother and Child Cohort Study (MoBa). Int. J. Epidemiol. 2016, 45, 382-388. [CrossRef] [PubMed]

15. Nohr, E.A.; Vaeth, M.; Bech, B.H.; Henriksen, T.B.; Cnattingius, S.; Olsen, J. Maternal obesity and neonatal mortality according to subtypes of preterm birth. Obs. Gynecol. 2007, 110, 1083-1090. [PubMed]

16. Nilsen, R.M.; Vollset, S.E.; Gjessing, H.K.; Schreuder, P.; Magnus, P. Self-selection and bias in a large prospective pregnancy cohort in Norway. Paediatr. Perinat. Epidemiol. 2009, 23, 597-608. [CrossRef] [PubMed]

17. Olsen, S.F.; Eva Birgisdottir, B.; Halldorsson, T.I.; Brantsæter, A.L.; Haugen, M.; Torjusen, H.; Petersen, S.B.; Strøm, M.; Meltzer, H.M. Possibilities and considerations when merging dietary data from the world's two largest pregnancy cohorts: The Danish National Birth Cohort and the Norwegian Mother and Child Cohort Study. Acta Obstet. Gynecol. Scand. 2014, 93, 1131-1140. [CrossRef]

18. Brantsæter, A.L.; Haugen, M.; Hagve, T.A.; Aksnes, L.; Rasmussen, S.E.; Julshamn, K.; Alexander, J.; Meltzer, H.M. Self-Reported Dietary Supplement Use Is Confirmed by Biological Markers in the Norwegian Mother and Child Cohort Study (MoBa). Ann. Nutr. Metab. 2007, 51, 146-154. [CrossRef] [PubMed] 
19. Brantsæter, A.L.; Haugen, M.; Alexander, J.; Meltzer, H.M. Validity of a new food frequency questionnaire for pregnant women in the Norwegian Mother and Child Cohort Study (MoBa). Matern. Child Nutr. 2008, 4, 28-43. [CrossRef]

20. Mikkelsen, T.B.; Osler, M.; Olsen, S.F. Validity of protein, retinol, folic acid and n-3 fatty acid intakes estimated from the food-frequency questionnaire used in the Danish National Birth Cohort. Public Health Nutr. 2006, 9, 771-778. [CrossRef] [PubMed]

21. Mikkelsen, T.B.; Olsen, S.F.; Rasmussen, S.E.; Osler, M. Relative validity of fruit and vegetable intake estimated by the food frequency questionnaire used in the Danish National Birth Cohort. Scand. J. Public Health 2007, 35, 172-179. [CrossRef] [PubMed]

22. Willett, W. Nutritional Epidemiology; Oxford University Press: Oxford, UK, 1990; pp. 273-307.

23. Boyle, J.D.; Boyle, E.M. Born just a few weeks early: Does it matter? Arch. Dis. Child. Fetal. Neonatal. Ed. 2013, 98, F85-F88. [CrossRef]

24. Morken, N.H.; Vogel, I.; Kallen, K.; Skjærven, R.; Langhoff-Roos, J.; Kesmodel, U.S.; Jacobsson, B. Reference population for international comparisons and time trend surveillance of preterm delivery proportions in three countries. BMC Women's Health 2008, 8, 16. [CrossRef]

25. Blencowe, H.; Lee, A.C.; Cousens, S.; Bahalim, A.; Narwal, R.; Zhong, N.; Chou, D.; Say, L.; Modi, N.; Katz, J.; et al. Preterm birth-associated neurodevelopmental impairment estimates at regional and global levels for 2010. Pediatr. Res. 2013, 74 (Suppl. 1), 17-34. [CrossRef] [PubMed]

26. Lu, M.S.; He, J.R.; Chen, Q.; Lu, J.; Wei, X.; Zhou, Q.; Chan, F.; Zhang, L.; Chen, N.; Qiu, L.; et al. Maternal dietary patterns during pregnancy and preterm delivery: A large prospective cohort study in China. Nutr. J. 2018, 17, 71. [CrossRef] [PubMed]

27. Lopez-Legarrea, P.; de la Iglesia, R.; Abete, I.; Navas-Carretero, S.; Martinez, J.A.; Zulet, M.A. The protein type within a hypocaloric diet affects obesity-related inflammation: The RESMENA project. Nutrition 2014, 30, 424-429. [CrossRef]

28. Hrolfsdottir, L.; Schalkwijk, C.G.; Birgisdottir, B.E.; Gunnarsdottir, I.; Maslova, E.; Granström, C.; Strøm, M.; Olsen, S.F.; Halldorsson, T.I. Maternal diet, gestational weight gain, and inflammatory marker during pregnancy. Obesity (Silver Spring) 2016, 24, 2133-2139. [CrossRef]

29. Kemp, M.W.; Saito, M.; Newnham, J.P.; Nitsos, I.; Okamura, K.; Kallapur, S.G. Preterm birth, infection, and inflammation advances from the study of animal models. Reprod. Sci. 2010, 17, 619-628. [CrossRef] [PubMed]

30. Kalagiri, R.R.; Carder, T.; Choudhury, S.; Vora, N.; Ballard, A.R.; Govande, V.; Drever, N.; Beeram, M.R.; Uddin, M.N. Inflammation in Complicated Pregnancy and Its Outcome. Am. J. Perinatol. 2016, 33, 1337-1356. [CrossRef] [PubMed]

31. Stephens, T.V.; Payne, M.; Ball, R.O.; Pencharz, P.B.; Elango, R. Protein requirements of healthy pregnant women during early and late gestation are higher than current recommendations. J. Nutr. 2015, 145, 73-78. [CrossRef] [PubMed]

32. Rifas-Shiman, S.L.; Rich-Edwards, J.W.; Willett, W.C.; Kleinman, K.P.; Oken, E.; Gillman, M.W. Changes in dietary intake from the first to the second trimester of pregnancy. Paediatr. Perinat. Epidemiol. 2006, 20, 35-42. [PubMed]

33. Cuco, G.; Fernandez-Ballart, J.; Sala, J.; Viladrich, C.; Iranzo, R.; Vila, J.; Arija, V. Dietary patterns and associated lifestyles in preconception,.pregnancy and postpartum. Eur. J. Clin. Nutr. 2006, 60, 364-371. [CrossRef]

34. Thörne, A. Diet-induced thermogenesis. An experimental study in healthy and obese individuals. Acta Chir. Scand. Suppl. 1990, $558,6-59$. 